\title{
Scottish Gaelic
}

Claire Nance

Lancaster University

c.nance@lancaster.ac.uk

Roibeard Ó Maolalaigh

University of Glasgow

Roibeard.OMaolalaigh@glasgow.ac.uk 


\section{Scottish Gaelic}

\section{Introduction}

Scottish Gaelic is a minority language of Scotland spoken by approximately 58,000 people, or $1 \%$ of the Scottish population (Census 2011). Here, we refer to the language as 'Gaelic', pronounced in British English as /galık/, as is customary within the Gaelic-speaking community. In Gaelic, the language is referred to as Gàidhlig/ka:lıc/. Gaelic is a Celtic language, closely related to Irish (MacAulay 1992, Ní Chasaide 1999, Gillies 2009). Although Gaelic was widely spoken across much of Scotland in medieval times (Withers 1984, Clancy 2009), the language has recently declined in traditional areas such as the western seaboard and western islands of Scotland and is now considered 'definitely endangered' by UNESCO classification (Moseley 2010). Analysis of the location of Gaelic speakers in Scotland and maps from the most recent Census in 2011 can be found in National Records of Scotland (2015). Figure 1 shows the location of Gaelic speakers in Scotland as a percentage of the inhabitants aged over three in each Civil Parish who reported being able to speak Gaelic in the 2011 Census.

$<$ INSERT FIGURE 1 ABOUT HERE $>$

A dialect of Gaelic in East Sutherland was once described as a prototypical case of language obsolescence (Dorian 1981) but the language is now undergoing significant revitalisation measures (e.g. McLeod 2006). These include the introduction of nursery, primary and secondary immersion schooling in Gaelic, as well as adult learning classes, more university degree courses, and many other public and private initiatives. Many of these activities are coordinated by the Gaelic Language Board (Bòrd na Gàidhlig), which was 
created as a result of the 2005 Gaelic Language Act (Scotland). The language act states that Gaelic holds the same legal status as English in Scotland.

The speaker in the speech samples associated with this contribution is a male in his fifties. He was born and raised in Ness, a Gaelic-speaking community in the north of the Isle of Lewis, and is currently working at the University of Glasgow. Lewis is the most northerly island in the chain of islands known as the Outer Hebrides, or the Western Isles. It is the part of Scotland where the densest concentration of Gaelic speakers resides (52\% Gaelic-speaking, 2011 Census). His speech can be considered representative of the middle-aged generation of fluent traditional Lewis Gaelic speakers, with some more levelled features due to his time in Glasgow among speakers of other dialects. We have noted where his Lewis dialect diverges significantly from other Hebridean dialects. The recordings were made onto a laptop computer in the noise-attenuated sound studio at the University of Glasgow using a Beyerdynamic Opus 55 headset and a Sound Devices USBPre2 pre-amplifier and analogueto-digital converter.

\section{Consonants}

\section{'Broad' and 'Slender'}

Similar to Irish, Gaelic consonants have a palatalised and a non-palatalised series. These are often referred to as 'slender' and 'broad' consonants respectively in the Gaelic literature and teaching materials (e.g. MacAulay 1992, Gillies 2009, Ó Maolalaigh \& MacAonghais 2008, Bauer 2011). Several consonants do not take part in this alternation: /m v h/. Borgstrøm (1940:17) suggests that no labial(-dental) consonants have the alternation in Scottish Gaelic but recent articulatory work on Irish confirms that in Irish $/ \mathrm{p}^{\mathrm{h}} \mathrm{p}$ f/ do have palatalised counterparts (Ní Chiosáin \& Padgett 2012), so we follow their work and Ladefoged et al. (1998). See also Oftedal (1965) and MacAulay (1968) for further comments on this topic. In 
Table 1 we have shown the non-palatalised series on the top row of each cell, and the palatalised series below where possible. Laterals, rhotics and alveolar/dental nasals are discussed separately below. Sample words are shown in Table 2.

\section{$<$ INSERT TABLE 1 ABOUT HERE $>$ \\ $<$ INSERT TABLE 2 ABOUT HERE $>$}

The only sounds with actively velarised counterparts are laterals and dental/alveolar nasals, which are discussed separately below. Some accounts of Irish have suggested that some other non-palatalised sounds are velarised, specifically $/ p^{8} b^{8} f^{8} m^{8} t^{y} d^{8} s^{8} /$

(Ní Chasaide 1999:35). This has not been reported for Gaelic, see Borgstrøm (1940:17), Gillies (2009:239), Ladefoged et al. (1998:3), Ternes (2006:18), Bosch (2010:268-269). Ní Chiosáin \& Padgett (2012:174) state that in Irish, the contrast is manifested as palatalised vs. non-palatalised before back vowels and palatalised vs. velarised before front vowels. In Irish, the example most commonly used is the contrast between bui 'yellow' $/ b^{\mathrm{y}} \mathrm{i} /$ and $b i$ 'be!' $/ \mathrm{b}^{\mathrm{j}} \mathrm{i} /$ (see Ní Chasaide 1999 for audio recordings). The analogous context in Gaelic is not

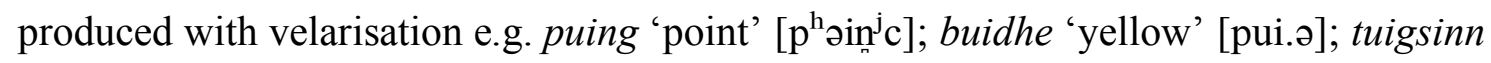

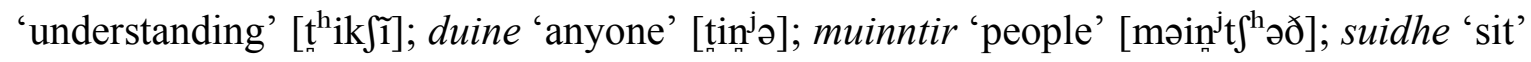
[sui.ə].

The broad/slender distinction manifests in a change of primary place of articulation for sounds produced further back than those discussed so far. For example, the palatalised dental/coronal stops are most commonly post-alveolar affricates, although some speakers produce alveolo-palatal affricates. Similarly, $/ \mathrm{S} /$ is the palatalised counterpart to $/ \mathrm{s} /$. The 
palatalised counterparts to $/ \mathrm{k}^{\mathrm{h}} /$ and $/ \mathrm{k} /$ are produced as palatal stops $/ \mathrm{c}^{\mathrm{h}} /$ and $/ \mathrm{c} /$ respectively (e.g. Borgstrøm 1940:17). /x/ and /ç/ are a broad and slender pair respectively, as are /y/ and $/ \mathrm{j} /$.

\section{Initial consonant mutations}

A feature common to all the Celtic languages is the existence of initial consonant mutations, a system of consonantal alternations under certain morphophonological conditions. The most common mutation in Gaelic, and the only one recognised in orthography, is lenition. This mutation occurs in contexts such as feminine singular nominative nouns after the definite article, feminine attributive adjectives, the dative case with the definite article, and the vocative of proper nouns. For full details about the contexts where lenition occurs see Ó Maolalaigh (1996) and Byrne (2002). Examples of lenition are show in Table 3. This table shows the broad transcription of lenited consonants; Archangeli et al. (2014) note there may be phonetic differences between lenited and 'underlying' consonants i.e. incomplete neutralisation (see also Welby et al. 2017 for incomplete neutralisation in Irish).

A second initial consonant mutation, not shown in orthography, and not realised in all dialects, is known as nasalisation or eclipsis. The phenomenon in Gaelic is somewhat different from the Irish phenomenon of eclipsis, which is recognised in orthography (Ó Maolalaigh 1996). In Gaelic, there is some dialectal variation in the realisation of eclipsis and its realisation is not obligatory. For details see Gillies (2009:251-252) and Ó Maolalaigh (1996). Eclipsis occurs after closely grammatically related items such as the definite article and noun or adjectives ending in a nasal consonant and noun. 


\section{Aspiration}

In word initial position, stops are either voiceless unaspirated or voiceless post-aspirated. In word-medial and word-final position, the stop series are either voiceless unaspirated or voiceless pre-aspirated (Borgstrøm 1940, Oftedal 1956, Ladefoged et al. 1998, Ó Maolalaigh 2010, Nance \& Stuart-Smith 2013). Pre-aspiration is typically longest in velar/palatal stops and shortest in bilabials. The realisation of preaspiration varies from dialect to dialect. In Lewis it is typically a voiceless [h], but preaspiration can be more [x]-like especially preceding velar stops in dialects such as Barra (see Ó Murchú 1985). Instrumental evidence in Nance \& Stuart-Smith (2013) suggest very little or no closure voicing even in word-medial stops which are orthographically $b d g$. For this reason we follow Ladefoged et al. (1998) in stating that the contrast is one of aspiration rather than voicing and use the transcriptions $/ \mathrm{p}^{\mathrm{h}} /$ and $/ \mathrm{p} /$ etc.

\section{Laterals, Nasals and Rhotics}

This subheading is shorthand to refer to laterals, dental/alveolar nasals and rhotics. Previous reports state that these sounds participate in a three-way contrast (Borgstrøm 1940, Oftedal 1956, Ní Chasaide 1979, Shuken 1980, Ladefoged et al. 1998, Ternes 2006, Nance 2013, 2014). In earlier forms of Gaelic, it is hypothesised that there was a four-way distinction between these sounds. The alleged distinction was as follows: palatalised and velarised dental variants contrasted with palatalised and velarised alveolar variants i.e. $/ 1_{n}^{\mathrm{j}} 1_{n}^{\mathrm{y}} 1^{\mathrm{j}} 1^{\mathrm{y}} /($ see, for example, Russell 1997:76). This previous four-way distinction has reduced to the three-way distinction, or two-way distinction in the case of rhotics, in most varieties of modern Gaelic 
(see Ternes 2006:19 for details). We refer to the three sounds as 'palatalised', 'velarised' and 'alveolar' as shorthand for their full descriptions.

\section{Laterals}

The laterals in modern Gaelic are a velarised dental lateral, a palatalised dental lateral, and an alveolar lateral. Following static palatographic work in Shuken (1980) and Ladefoged et al. (1998), and descriptions in Borgstrøm (1940) and Oftedal (1956), we consider the palatalised lateral as palatalised, rather than palatal. Acoustically, the velarised lateral is characterised by low F2 and high F1, the palatalised lateral by high F2 and low F1, and the alveolar lateral lies in between these two extremes (Shuken 1980, Ladefoged et al. 1998, Nance 2013, 2014).

In word-initial position, our speaker produces three laterals: the velarised and palatalised laterals differ substantially e.g. loch 'lake' $/ 1_{n}^{1} \mathrm{ox} /$ and leabaidh 'bed' $/ 1_{n}^{\mathrm{j}}$ api/. Very few lexical items, excluding recent borrowings, begin with the alveolar lateral, but this can be derived through the lenition initial consonant mutation. Generally speaking, the velarised and palatalised laterals, nasals and rhotics lose their secondary articulations in lenition conditions. For example, the lenited palatalised lateral becomes alveolar e.g. leabaidh, 'bed' $/ \mathrm{ln}^{\mathrm{j}}$ api/ but mo leabaidh 'my bed' /mo lapi/. It has been reported that a lenited velarised lateral will become alveolar, but our speaker did not make this distinction. In word-medial position, there is a straightforward three-way contrast e.g. callaid 'fence' $/ \mathrm{k}^{\mathrm{h}} \mathrm{al}{ }^{\mathrm{\gamma}} \mathrm{at} \mathrm{J} /$, coileach 'cockerel' $/ \mathrm{k}^{\mathrm{h}}$ alox/, cailleach 'old woman' $/ \mathrm{k}^{\mathrm{h}} \mathrm{a}_{n}^{\mathrm{j}} \mathrm{ox} /$. Similarly, there is a three-way contrast in wordfinal position e.g. dall 'blind' /tauln 1 , dàil 'delay' /ta:l/, caill 'lose' $/ \mathrm{k}^{\mathrm{h}}$ ail ${ }_{n}^{\mathrm{j}} /$. 


\section{Nasals}

Descriptions in Borgstrøm (1940) and static palatography in Shuken (1980) describe the articulation of the three (dental/alveolar) nasals as $/ \mathrm{n}_{n}^{\mathrm{y}} /, / \mathrm{n} /$ and $/ \mathrm{n}^{\mathrm{j}} /$. Velar and palatal variants of these sounds occur in the context of /k/ and /c/, for example long 'ship' [11 rãũy], and taing 'thanks' [ $\mathrm{t}^{\mathrm{h}}$ ãinc]. As these are the only contexts where $[\mathrm{\eta}]$ and [n] occur we consider them as allophones of $/ \mathrm{n}^{\mathrm{V}} /$ and $/ \mathrm{n}^{\mathrm{j}} /$ respectively (see also Borgstrøm 1940:77).

In word-initial position, there is a contrast between velarised and palatalised nasals, e.g. nach 'not' $/ \mathrm{n}^{\mathrm{V}} \mathrm{ax} /$, and neach 'person' $/ \mathrm{n}^{\mathrm{j}} \mathrm{ax} /$. Very few lexical items begin with alveolar nasal, but this can be derived through lenition. The lenitied palatalised nasal becomes alveolar e.g. nighean 'daughter' $/ \mathrm{n}_{\mathrm{j}}^{\mathrm{j}} \mathrm{i} . ə \mathrm{n} /$, mo nighean 'my daughter' /mo ni.ən/. Theoretically, the lenited velarised also becomes alveolar, but our speaker did not make this distinction. In word-medial position, there is a three-way contrast e.g. Anna 'Anna' /ann`ə/, banais 'wedding' /benIS/, bainne 'milk' /bonn $n^{\mathrm{j}} \mathrm{\jmath} /$. In word-final position, there is a three-way contrast e.g. seann

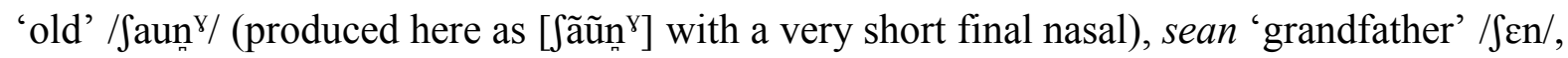
seinn 'singing' / $\int \operatorname{\partial in}_{n}^{\mathrm{j}} /$.

\section{Rhotics}

The rhotics also historically participated in the three-way distinction between velarised, alveolar and palatalised phonemes (Borgstrøm 1940, Oftedal 1956). In modern Gaelic however, most speakers have merged the velarised and alveolar rhotics (Ladefoged et al. 1998). Traditional descriptions indicate that the velarised rhotic is produced as a velarised trill (Borgstrøm 1940, Oftedal 1956), but most speakers now produce the velarised/alveolar 
rhorics as taps or approximants, and trills are very rare in contemporary production (Ó Dochartaigh 1997, Nance et al. 2016). The palatalised rhotic is often produced as a dental fricative [ð] in Lewis and in other dialects. There is, however, substantial variation across dialects in the production of this sound, with many dialects and individuals producing some kind of tap or fricated tap (Ó Dochartaigh 1997). We have represented the current two-way contrast as a distinction between $/ \mathrm{f} /$ and $/ \mathrm{f}^{\mathrm{j}} /$ but it should be noted that there is substantial variation in the production of these sounds.

In word-initial position, the palatalised variant is almost non-existent so the contrast is effectively neutralised. The preposition $r i$ ' $t o$ ' $/ \mathrm{r}^{\mathrm{j}} \mathrm{i} /$ is reported to use the palatalised variant, but our speaker did not produce this rhotic substantially different to the rhotic in, for example, ràdh 'saying' /ra:/. In word-medial position, there is a two-way contrast e.g. aran 'bread' /aran/, aire 'attention' $/ \mathrm{ar}^{\mathrm{j} ə /}$ (produced as [aðə]). In word-final position there is also a twoway contrast e.g. car 'somewhat' $/ \mathrm{k}^{\mathrm{h}} \mathrm{ar} /$, air 'on' $/ \varepsilon^{\mathrm{j}} /$ (produced as [عð]).

In the dialect presented here, clusters with rhotics, dental/alveolar stops, laterals, and nasals tend to be produced as retroflex, and the rhotic as a retroflex approximant; for example, thuirt 'said' [htrt]. In -rs clusters, the rhotic and sibilant are often produced as retroflex; e.g. carson 'why' [ $\mathrm{k}^{\mathrm{h}}$ arșon]. In the vast majority of other Gaelic dialects, an audible [S] or [s] occurs in -rt clusters; e.g. thuirt 'said' [htrst]; in some dialects this also occurs in -rd (Watson 1990). 


\title{
Vowels
}

\section{Monophthongs}

Gaelic has nine oral monophthongs, which can be long or short, these are shown in Figure 2 (acoustic data from the recording samples in this illustration). For acoustic analysis of a larger dataset focussing on the high back vowels, see Nance (2011). Sample words are given in Table 4. Long vowels are indicated by an accent grave in orthography. Generally, the long vowels are of similar acoustic quality to the short vowels, although they tend to be slightly more peripheral. The 'high back' vowels $/ \gamma \mathrm{w} /$ are acoustically more central, or even front in the dialect represented here (Nance 2011). Borgstrøm (1940:11) describes these vowels as phonologically, rather than phonetically, back. The two previous dialect descriptions of Lewis Gaelic, Borgstrøm and Oftedal, do not use the modern IPA. We follow Ladefoged et al. (1998) in interpreting their symbols as $/ \gamma /$ and /u/. The vowel $/ \mathrm{u} /$ has two allophones, back $[\underline{u}]$ occurring in the environment of velarised sonorants, and central $[\mathrm{u}]$ occurring elsewhere;

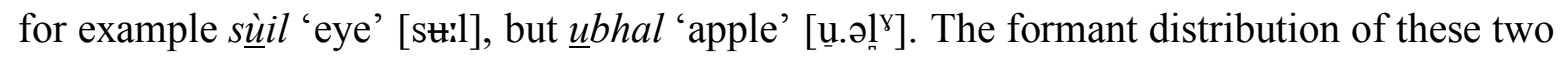
allophones is strikingly different; see Ladefoged et al. (1998) and Nance (2011). Similarly, /a/ is auditorily [a] in the environment of velarised sonorants; for example latha 'day' [1 $\left.{ }^{\mathrm{y}} \mathrm{a} . ə\right]$, but leat 'at you' $\left[\mathrm{la}^{\mathrm{h}} \mathrm{t}\right]$. Long / $\varepsilon$ :/ is not common and has merged with /e:/ for some speakers, including our participant. In Lewis, a group of words containing orthographic ea before $g$ are pronounced with $/ \gamma /$, but /ع/ or /e/ in other dialects; e.g. beag 'small', eaglais 'church'.

\author{
$<$ INSERT VOWEL QUADRILATERAL ABOUT HERE $>$ \\ $<$ INSERT FIGURE 2 ABOUT HERE $>$ \\ $<$ INSERT TABLE 4 ABOUT HERE $>$
}




\section{Nasal monophthongs}

There are disagreements in the literature with reference to the number of nasal vowels in Gaelic, and their nature. Borgstrøm (1940:13) reports five short nasal vowel phonemes, and six long nasal vowel phonemes. Oftedal (1956:40), who was reporting on a dialect on the eastern side of Lewis, describes nine short and seven long nasal vowel phonemes. It is also important to note that Borgstrøm and Oftedal recorded participants born in the 1880s and before, and this may not represent the contemporary situation. Even from these recordings, Oftedal notes that nasality in vowels in 'one of the most elusive features' of the phonemics of the dialect under investigation (1956:40), and suggests that nasality has 'little distinctive value', referring to its very low functional load. Similarly, Borgstrøm (1940:13) states that nasality has 'not a great functional value'. The degree of nasality appears to vary from dialect to dialect and is also to some extent speaker-specific. Oftedal (1956:41) notes that even between two of his participants, who were from the same village and married, there was great variation as to the degree of nasality among their vowels. One person, he claimed, had nasal vowels perceptibly similar to nasal vowels in French, whereas the other speaker has nasal vowels similar to a speaker of General American (see also Ó Curnáin 2009 for analysis of individuals in Irish). When listening to our sample sound files, there appears to be variable amounts of nasality on different words, shown in Table 5. See Warner et al. (2015) and Morrison (2015) for analysis of nasal airflow data. The quality of the nasal vowels is similar to that of their oral counterparts so they are not repeated in a figure here.

Nasal vowels in Gaelic generally arose due to coarticualtion with an original nasal consonant; for example tàmh 'rest' /thã̃iv/. In this word, the orthographic $m$ suggests there

was a bilabial nasal consonant historically, which is no longer pronounced. See Ó Maolalaigh (2003) for an account of nasalisation processes in Gaelic. Some accounts suggest that the final 
fricative in words such as tàmh is also nasalised (Borgstrøm 1940, Ternes 2006), but aerodynamic work suggests that this is not the case phonetically (in Warner et al.'s 2015 work on Skye, but see also Morrison 2015), and it has been suggested that these are unlikely in articulatory terms (Ohala 1975:300).

$<$ INSERT TABLE 5 ABOUT HERE $>$

\section{Diphthongs}

Gaelic has a rich diphthongal system. Borgstrøm (1940:37) describes 14 phonemic

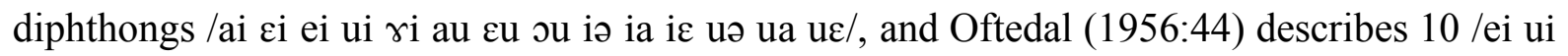
əi ai ou au iə ia uə ua/. We find that Oftedal's account best describes contemporary Gaelic. These two previous descriptions do not specifically mention whether nasality in diphthongs should be considered a phonemic aspect or not. However, both give examples of nasal diphthongs. We asked our speaker to produce a large number of words listed by Borgstrøm and Oftedal as containing nasal diphthongs, but these were not consistently audibly nasal. We consider the contemporary situation to be that some words contain diphthongs with nasalisation, but nasalised diphthongs are not phonemic in the language. Sample words are given in Table 6.

$<$ INSERT DIPTHONG REPRESENTATION HERE $>$

$<$ INSERT TABLE 6 ABOUT HERE $>$ 


\section{Prosody}

\section{Syllables, svarabhakti and hiatus}

Gaelic syllable structure has been described as typically VC rather than the typologically much more common CV (Clements 1986, Bosch 1998, Smith 1999). See Ní Chiosáin et al. (2012) for experimental work on syllabification in Irish and similar discussion. Two classes of Gaelic words will be described in more detail here, as they behave unusually within Gaelic phonology: words containing a svarabhakti vowel, and 'hiatus' words. Certain consonant sequences in Gaelic are broken up by a svarabhakti vowel, which is not represented in the orthography; for example, arm ‘army’ [aram], ainm 'name' [anam], balg ‘belly’ [paln 'ak], dorcha 'dark' [troroxə], Alba 'Scotland' [aln ${ }^{\mathrm{Y}}$ apə]. Usually the svarabhakti vowel is a copy of the preceding vowel (Borgstrøm 1940, Clements 1986, Bosch \& de Jong 1997, Hall 2006). Svarabhakti vowels in Gaelic occur where (1) The consonant preceding the svarabhakti vowel is a sonorant, (2) The preceding vowel is short, (3) The consonant cluster is non-homorganic, and (4) The second consonant is not a pre-aspirated plosive. Previous descriptions state that svarabhakti vowels do not contribute to the syllable count of a word; for example, falbh 'going' [fal ${ }_{n}^{\mathrm{Y} a v}$ is monosyllabic, but falamh 'empty' [fal $\left.{ }^{\mathrm{Y}} \cdot \mathrm{u}\right]$ is disyllabic (Borgstrøm 1940, Oftedal 1956, Bosch 1998). Recent experimental work (Hammond et al. 2014) suggests that speaker perceptions are more complex: they found that words such as falbh were perceived as not quite monosyllabic, but not quite disyllabic either. The svarabhakti vowels are described as stressed, which is unusual for stress-initial Gaelic and also typologically (Borgstrøm 1937:77; Bosch \& de Jong 1997).

'Hiatus' words in most cases refer to a class of words in which historic intervocalic

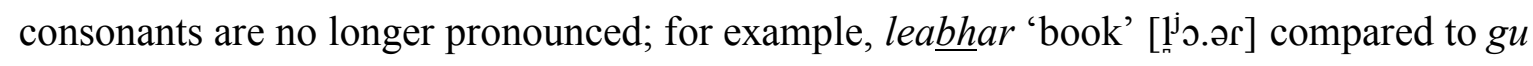

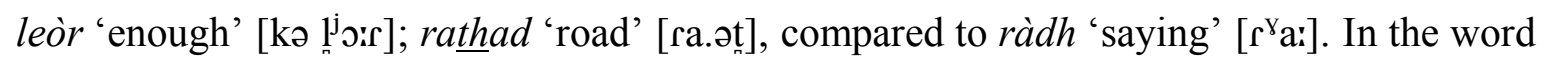


accent system of (Lewis) Gaelic (see below), words with a svarabhakti vowel such as falbh 'going' [fal $\left.{ }^{\mathrm{Y} a v}\right]$ are produced with the accent for monosyllabic words and words with hiatus such as leabhar 'book' []$\left._{r}^{\mathrm{j}} \mathrm{\partial} . ə r\right]$ are produced with the accent for polysyllabic words. In other dialects, hiatus is produced with an inserted glide, a period of creaky voice or a glottal stop (Holmer 1938, Jones 2000, Ternes 2006:138).

\section{Tone, intonation and stress}

The Lewis dialect of Gaelic, along with north-west mainland dialects such as Applecross, is described as having contrastive word accents (Borgstrøm 1940, Oftedal 1956, Dorian 1978, Bosch \& de Jong 1997, Ladefoged et al. 1998, Ternes 2006, Iosad 2015, Nance 2015a, Morrison forthcoming). Southern Hebridean and other mainland dialects are not reported to use this prosodic feature (see Ternes 2006:138 for details). Ternes (2006) provides the most complete extensive of the Lewis Gaelic system. In this account, word accents correspond to differences in syllabicity: monosyllabic words have a rising or level low pitch, whereas polysyllabic words have a level high pitch, falling pitch, rising-falling pitch. This is schematised in Figure 3. In general, speakers are often not consciously aware that their dialect uses pitch contrastively. When Gaelic is taught, the dialects of Skye or Uist are more often used as models, so tone is rarely, if ever, explicitly taught. Example pairs of words illustrating the contrast are in Table 7, and spectrograms of the contrast between falbh 'going' [fal ${ }^{\mathrm{Y} a v}$ ] and falamh 'empty' [fal $\left.{ }^{\mathrm{y}} \cdot \mathrm{u}\right]$ are shown in Figure 4. Analysis of the word accent system from a corpus of spontaneous speech is presented in Nance $(2013,2015 a)$.

$<$ INSERT FIGURE 3 ABOUT HERE > 
$<$ INSERT FIGURE 4 ABOUT HERE $>$

In terms of sentence intonation, the default pattern in declaratives is a fall in pitch (Oftedal 1956:36, Dorian 1978:37, MacAulay 1979). Borgstrøm (1940:53) additionally states that if the last syllable has a (lexical) rising word accent, the rise is often very reduced. MacAulay's descriptive account of common pitch patterns in Lewis intonation suggests that interrogatives may be realised with rising pitch.

In the vast majority of Gaelic words, the word-initial syllable is stressed. Exceptions are generally borrowings such as buntàta [pun't $\left.{ }^{\mathrm{h}} \mathrm{a} \mathrm{:}^{\mathrm{h}} \mathrm{t}\right]$ 'potatoes' and some adverbs such as andiugh 'today' [ən'tf $\mathrm{t}$ ] and days of the week e.g. Didòmhnaich 'Sunday' [tfi'tõ:.niç]. Words containing a svarabhakti vowel (see above) are unusual in terms of stress and it has been claimed that both vowels bear stress (Bosch \& de Jong 1997).

\section{Airstream mechanisms}

A final notable feature of Gaelic prosody is the extensive use of the ingressive airstream mechanism, especially in the last word of a phrase and discourse markers expressing agreement (Lamb 2003, Thom 2005, Eklund 2008). This use of ingressives is informally referred to as the 'Gaelic gasp'.

\section{Sociolinguistic variation}

Gaelic's endangered and minority status means that the language is susceptible to rapid and extensive change. This illustration discusses the phonetic and phonological characteristics of conservative Gaelic as spoken by older or middle-aged speakers from (at least formerly) Gaelic-dominant communities. Younger speakers may sound substantially different to the 
variety of Gaelic described here. For example, nasal vowels are rare in the speech of younger speakers (see also Ó Curnáin 2009:333 for Irish). The word accent system described above is not used by younger speakers from any background (Nance 2015a, Nance 2015b). Some younger speakers do not produce the three-way lateral contrast (Nance 2014, Nance 2019).

\section{Transcription of recorded passage}

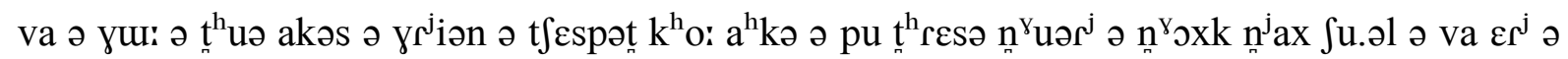

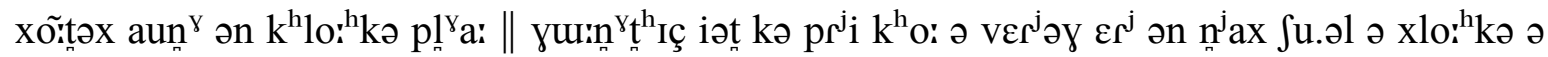

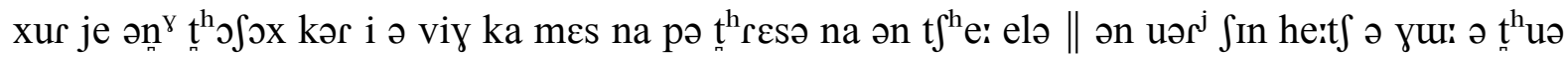

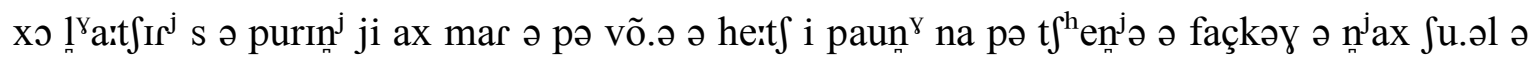

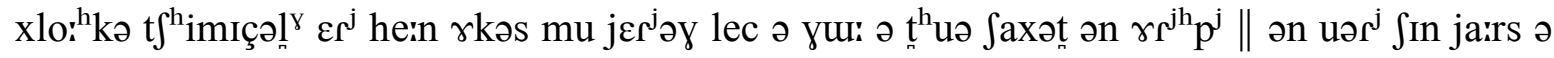

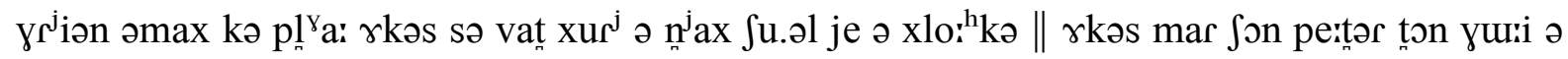

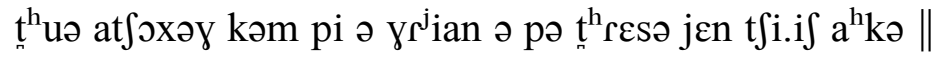

\section{Orthographic version}

Bha a' ghaoth a tuath agus a' ghrian a' deasbad cò aca a bu treasa nuair a nochd neachsiubhail a bha air a chòmhdach ann an cleòca blàth. Dh' aontaich iad ge brith cò a bheireadh air an neach-siubhail a chleòca a chur dheth an toiseach gur i a bhiodh ga meas na bu treasa na an tè eile. An uair sin shèid a' ghaoth a tuath cho làidir 's a b'urrainn dhi, ach mar a bu mhotha a shèid i b' ann na bu teinne a phaisgeadh an neach-siubhail a chleòca timcheall air fhèin agus mu dheireadh leig a' ghaoth a tuath seachad an oidhirp. An uair sin dheàrrs a' 
ghrian a-mach gu blàth agus sa bhad chuir an neach-siubhail dheth a chleòca. Agus mar sin, b'fheudar don ghaoith a tuath aideachadh gum b' i a' ghrian a bu treasa den dithis aca.

\section{Acknowledgements}

We are very grateful to our speaker for contributing the recordings, to Sìm Innes (University of Glasgow) for assistance in preparing the translation of the North Wind and the Sun passage, and to Cassie Smith-Christmas (University of Galway) for comments on the materials used. Thank you to Glasgow University Laboratory of Phonetics for use of their facilities while recording. Thank you to Amalia Arvaniti, the anonymous reviewers, Sam Kirkham and Adrian Leeman for their helpful and constructive comments. 


\section{References}

Archangeli, Diana, Sam Johnston, Jae-Hyun Sung, Murial Fisher, Michael Hammond \& Andrew Carnie. 2014. Articulation and neutralization: A preliminary study of lenition in Scottish Gaelic. Proceedings of the Annual Conference of the International Speech Communication Association, INTERSPEECH. 1683-1687.

Ball, Martin \& Nicole Müller (eds.). 2009. The Celtic languages. London: Routledge, 2nd edn.

Bauer, Michael. 2011. Blas na Gàidhlig: The practical guide to Gaelic pronunciation. Glasgow: Akerbeltz.

Borgstrøm, Carl. 1937. The dialect of Barra in the Outer Hebrides. Norsk Tidsskrift for Sprogvidenskap 7, 71-242.

Borgstrøm, Carl. 1940. The dialects of the Outer Hebrides, vol. 1. Olso: Norsk Tidsskrift for Sprogvidenskap.

Bosch, Anna. 1998. The syllable in Scottish Gaelic dialect studies. Scottish Gaelic Studies 18, $1-22$.

Bosch, Anna. 2010. Phonology in modern Gaelic. In Moray Watson \& Michelle Macleod (eds.) The Edinburgh companion to the Gaelic language, 262-282, Edinburgh: Edinburgh University Press.

Bosch, Anna \& Kenneth de Jong. 1997. The prosody of Barra Gaelic epenthetic vowels. Studies in the Linguistic Sciences 27(1), 1-16.

Bruce, Gösta. 1977. Swedish word accents in sentence perspective. Lund: Gleerup.

Byrne, Michel. 2002. Gràmar na Gàidhlig. Stòrlann-Acair: Isle of Lewis.

Clancy, Thomas. 2009. Gaelic in Medieval Scotland: Advent and expansion. Proceedings of the British Academy 167, 349-392. 
Clements, George, N. 1986. Syllabification and epenthesis in the Barra dialect of Gaelic. In Koen Bogers \& Harry Van der Holst (eds.) The phonological representation of suprasegmentals, 317-336, Dordrecht: Foris.

Dorian, Nancy. 1978. East Sutherland Gaelic: The dialect of the Brora, Golspie, and Embo fishing communities. Dublin: Dublin Institute for Advanced Studies.

Dorian, Nancy. 1981. Language death: The life cycle of a Scottish Gaelic dialect. Philadelphia: University of Pennsylvania Press.

Eklund, Robert. 2008. Pulmonic ingressive phonation: Diachronic and synchronic characteristics, distribution and function in animal and human sound production and in human speech. Journal of the International Phonetic Association 38, 235-324.

Gillies, William. 2009. Scottish Gaelic. In Martin Ball \& Nicole Müller (eds.) The Celtic languages, 230-305, London: Routledge, 2nd edn.

Hall, Nancy. 2006. Cross-linguistic patterns of vowel intrusion. Phonology 23, 387-429.

Hammond, Michael, Natasha Warner, Andréa Davis, Andrew Carnie, Diana Archangeli \& Muriel Fisher. 2014. Vowel insertion in Scottish Gaelic. Phonology 31, 123-151.

Holmer, Nils M. 1938. Studies on Argyllshire Gaelic. Skrifter utgivna av Kungliga Humanistiska Vetenskapssamfundet i Uppsala 31. Uppsala: Almqvist \& Wiksell. Iosad, Pavel. 2015. 'Pitch accent' and prosodic structure in Scottish Gaelic: Reassessing the role of contact. In Martin Hilpert, Janet Duke, Christine Mertzlufft, Jan-Ola Östman \& Michael Rießler (eds.) Advances in Nordic linguistics, 28-54, Berlin: Mouton de Gruyter.

Jones, George. 2000. Beagan mu'n stad ghlotasach ann an Gàidhlig Ceann a Deas Earraghaidheil. Scottish Gaelic Studies 20, 201-211. 
Ladefoged, Peter, Jenny Ladefoged, Alice Turk, Kevin Hind \& St. John Skilton. 1998. Phonetic structures of Scottish Gaelic. Journal of the International Phonetic Association 28, 1-41.

Lamb, Will. 2003. Scottish Gaelic. Munich: Lincom Europa.

MacAulay, Donald. 1968. Palatization of labials in Scottish Gaelic and some related problems in phonology. Scottish Gaelic Studies 11, 72-84.

MacAulay, Donald. 1979. Some functional and distributional aspects of intonation in Scottish Gaelic: A preliminary study of tones. In Dónall Ó Baoill (ed.) Papers in Celtic phonology, 27-38, Coleraine: New University of Ulster.

MacAulay, Donald. 1992. The Celtic languages. Cambridge: Cambridge University Press.

McLeod, Wilson. 2006. Revitalising Gaelic in Scotland: Policy, planning and public discourse. Edinburgh: Dunedin Academic Press.

Morrison, Donald. 2015. Vowel nasalisation in Scottish Gaelic. Unpublished BA thesis, University of Manchester, Manchester.

Morrison, Donald. Forthcoming. Metrical structure in Scottish Gaelic: Tonal accent, glottalisation and overlength. Phonology.

Moseley, Christopher (ed.). 2010. Atlas of the world's languages in danger. Paris: UNESCO Publishing. 3rd edn. Online version: http://www.unesco.org/culture/en/endangeredlanguages/atlas

Nance, Claire. 2011. High back vowels in Scottish Gaelic. In Proceedings of the 17th International Congress of the Phonetic Sciences, Hong Kong: City University Hong Kong.

Nance, Claire. 2013. Phonetic variation, sound change, and identity in Scottish Gaelic. Ph.D. thesis, University of Glasgow, Glasgow. 
Nance, Claire \& Jane Stuart-Smith. 2013. Pre-aspiration and post-aspiration in Scottish Gaelic stop consonants. Journal of the International Phonetic Association 43(2), 129152.

Nance, Claire. 2014. Phonetic variation in Scottish Gaelic laterals. Journal of Phonetics 47, $1-17$.

Nance, Claire. 2015a. Intonational variation and change in Scottish Gaelic. Lingua 160, 1-19.

Nance, Claire. 2015b. 'New' Scottish Gaelic speakers in Glasgow: A phonetic study of language revitalisation. Language in Society 44, 553-579.

Nance, Claire. 2019. Bilingual language exposure and the peer group: Acquiring phonetics and phonology in Gaelic Medium Education. International Journal of Bilingualism. Online first.

Nance, Claire, Wilson McLeod, Bernadette O’Rourke and Stuart Dunmore. 2016. Identity, accent aim, and motivation in second language users: New Scottish Gaelic speakers' use of phonetic variation. Journal of Sociolinguistics 20(2), 164-191.

National Records of Scotland. 2015. Scotland's Census 2011: Gaelic report (part 1). Edinburgh: Official Statistics publications for Scotland. Available at: http://www.scotlandscensus.gov.uk/documents/analytical_reports/Report_part_1.pdf

Ní Chasaide, Ailbhe. 1979. Laterals of Gaoth-Dobhair Irish and of Hiberno English. In Dónall Ó Baoill (ed.) Papers in Celtic phonology, 54-78, Coleraine: New University of Ulster.

Ní Chasaide, Ailbhe. 1999. Irish. In Handbook of the International Phonetic Association, Cambridge: Cambridge University Press.

Ní Chiosáin, Máire \& Jaye Padgett. 2012. An acoustic and perceptual study of Connemara Irish palatalization. Journal of the International Phonetic Association 42, 171-191. 
Ní Chiosáin, Máire, Pauline Welby \& Robert Espesser. 2012. Is the syllabification of Irish a typological exception? An experimental study. Speech Communication 54, 68-91.

Ó Curnáin, Brian. 2007. The Irish of Iorras Aithneach, County Galway. Dublin: Dublin Institute for Advanced Studies.

Ó Dochartaigh, Cathair (ed.). 1997. Survey of the Gaelic dialects of Scotland. Dublin: Dublin Institute for Advanced Studies.

Ohala, John. 1975. Phonetic explanations for nasal sound patterns. In Nasálfest: papers from a symposium on nasals and nasalization, Charles A. Ferguson, Larry M. Hyman \& John J. Ohala (eds.) 289-316. Stanford: Language Universals Project.

Ó Maolalaigh, Roibeard. 1996. The development of eclipsis in Gaelic. Scottish Language 14, $158-173$.

Ó Maolalaigh, Roibeard. 2003. Processes in nasalization and related issues. Ériu 53, 109-132.

Ó Maolalaigh, Roibeard. 2010. The sound of silence: Some structural observations on preaspiration in Scottish Gaelic. In Wilson. McLeod, A. Burnveat, D. Stiubhart, Thomas Clancy \& Roibeard Ó Maolalaigh (eds.) Bile ós Chrannaibh: A festschrift for William Gillies, Ceann Drochaid: Clann Tuirc.

Ó Maolalaigh, Roibeard \& Iain MacAonghuis. 2008. Scottish Gaelic in twelve weeks. Edinburgh: Birlinn.

Ó Murchú, Máirtín. 1985. Devoicing and pre-aspiration in varieties of Scots Gaelic. Ériu 36, $195-198$.

Oftedal, Magnus. 1956. A linguistic survey of the Gaelic dialects of Scotland. Vol III: The Gaelic of Leurbost, Isle of Lewis. Oslo: Norsk Tidsskrift for Sprogvidenskap.

Oftedal, Magnus. 1965. On ‘palatalized’ labials in Scottish Gaelic. Scottish Gaelic Studies 10, $71-81$.

Russell, Paul. 1995. An introduction to the Celtic languages. New York: Longman. 
Shuken, Cynthia. 1980. An instrumental investigation of some Scottish Gaelic consonants. $\mathrm{Ph} . \mathrm{D}$. thesis, University of Edinburgh, Edinburgh.

Smith, Norval. 1999. A preliminary account of some aspects of Leurbost Gaelic syllable structure. In Harry Van der Hulst \& Elizabeth Ritter (eds.) The Syllable: Views and facts, 577-630, Berlin: Mouton de Gruyter.

Ternes, Elmar. 2006. The phonemic analysis of Scottish Gaelic. Dublin: Dublin Institute for Advanced Studies, 3rd edn.

Thom, Eleanor. 2008. The Gaelic Gasp and its North Atlantic cousins: A study of ingressive pulmonic speech in Scotland. Unpublished MA thesis, University College London.

Warner, Natasha, Daniel Brenner, Jessamyn Schertz, Andrew Carnie, Muriel Fisher \& Michael Hammond. 2015. The aerodynamic puzzle of nasalized fricatives: Aerodynamic and perceptual evidence from Scottish Gaelic. Laboratory Phonology 6, $197-241$.

Watson, Seosamh. 1990. On the development of the group -rt in Scottish Gaelic. Celtica, 21, $664-669$.

Welby, Pauline, Máire Ní Chiosáin \& Brian Ó Raghallaigh. 2017. Total eclipse of the heart? The production of eclipsis in two speaking styles of Irish. Journal of the International Phonetic Association, 47, 125-153.

Withers, Charles. 1984. Gaelic in Scotland 1698-1981: The geographical history of a language. Edinburgh: John Donald. 


\section{Footnotes}

There are three footnotes in this illustration.

The first footnote is in the caption to Figure 1. This footnote is currently in captions document

The second footnote is in Table 1. This footnote is currently in the Tables document.

The third footnote is in Table 2. This footnote is currently in the Tables document.

As requested, the footnotes are currently numbered automatically so this will need to be updated when they are included in the main document. 


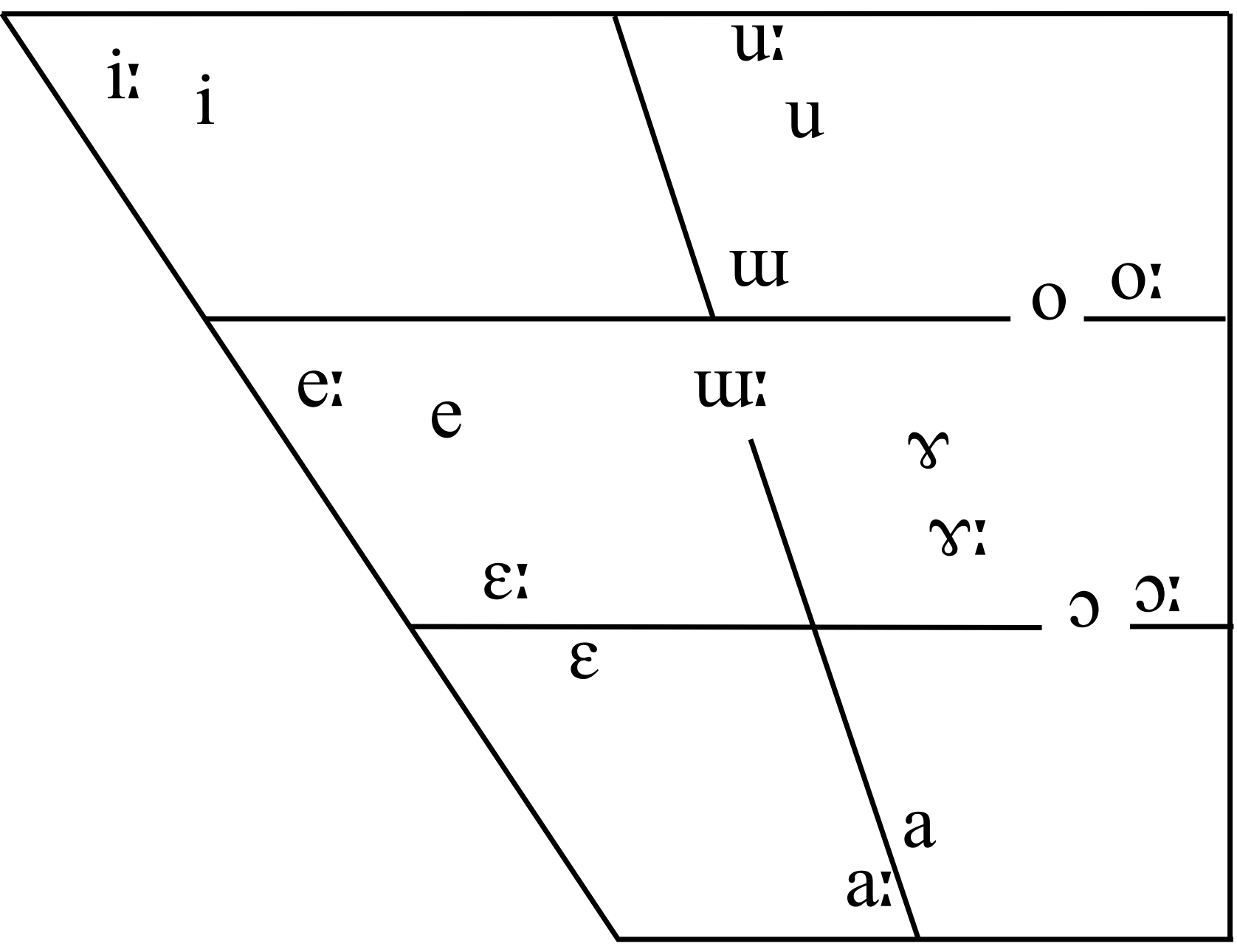




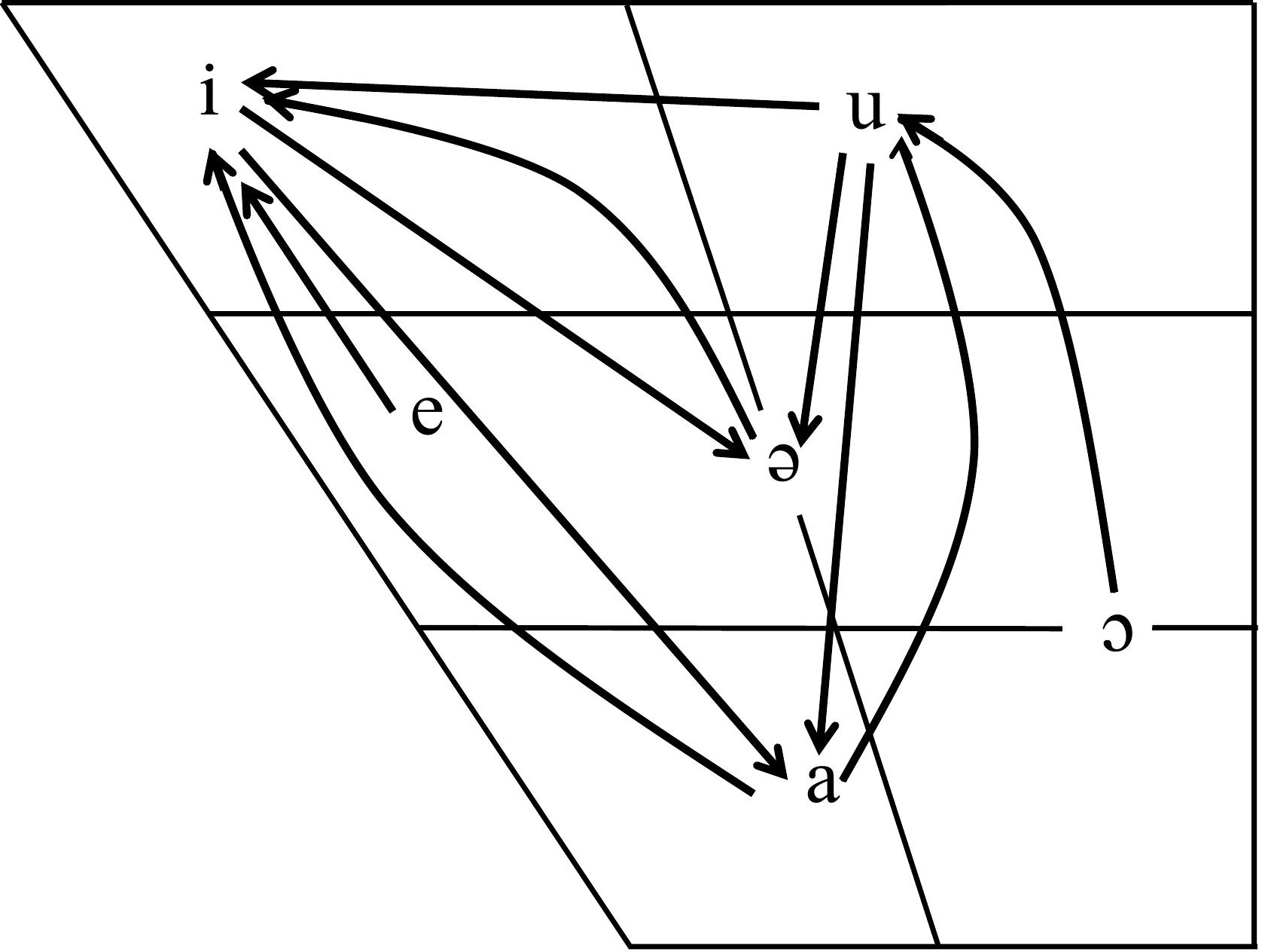


$0 \%$ to $1 \%$

$1 \%$ to $5 \%$

$5 \%$ to $10 \%$

$10 \%$ to $25 \%$

$25 \%$ to $50 \%$

$>50 \%$
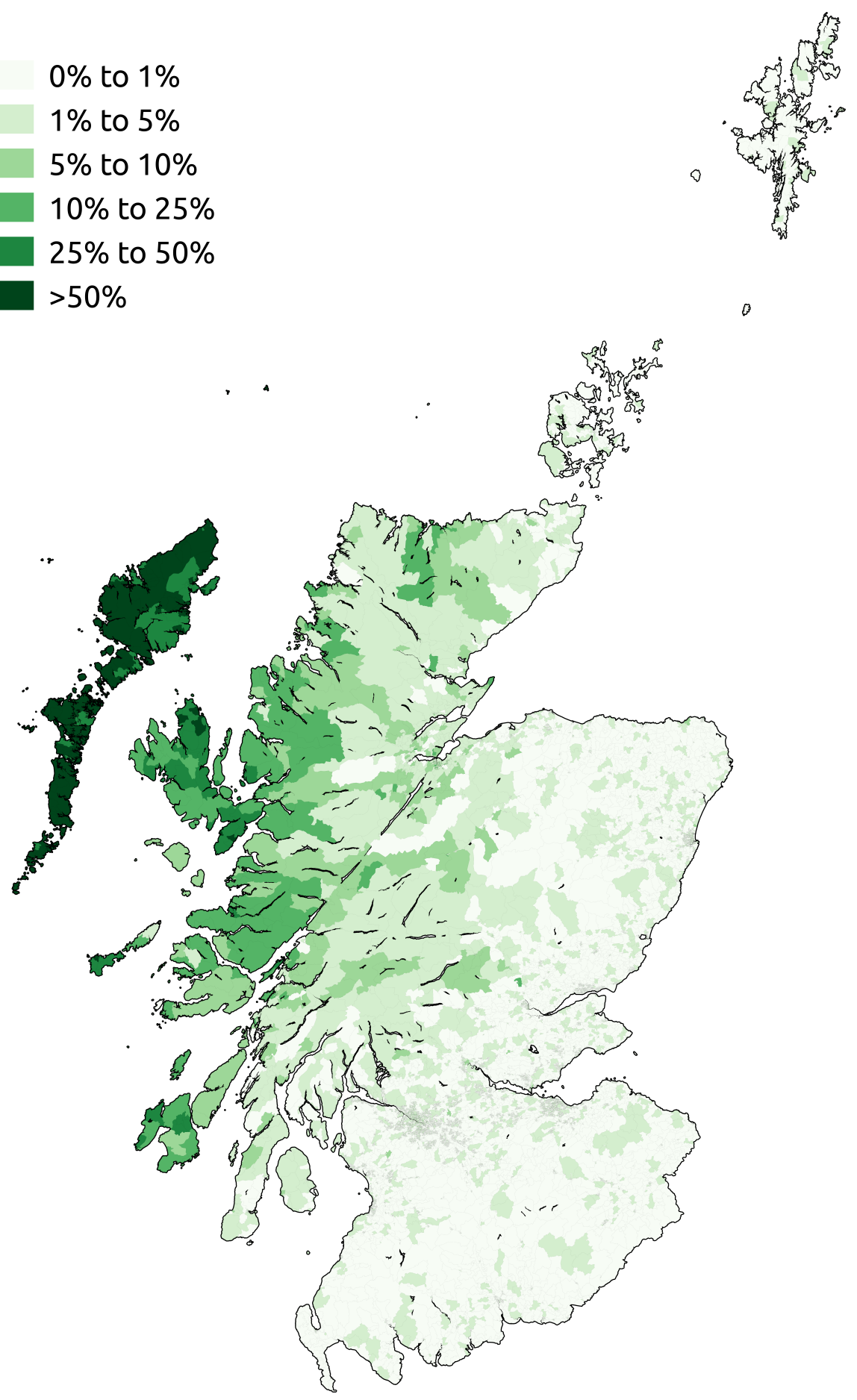

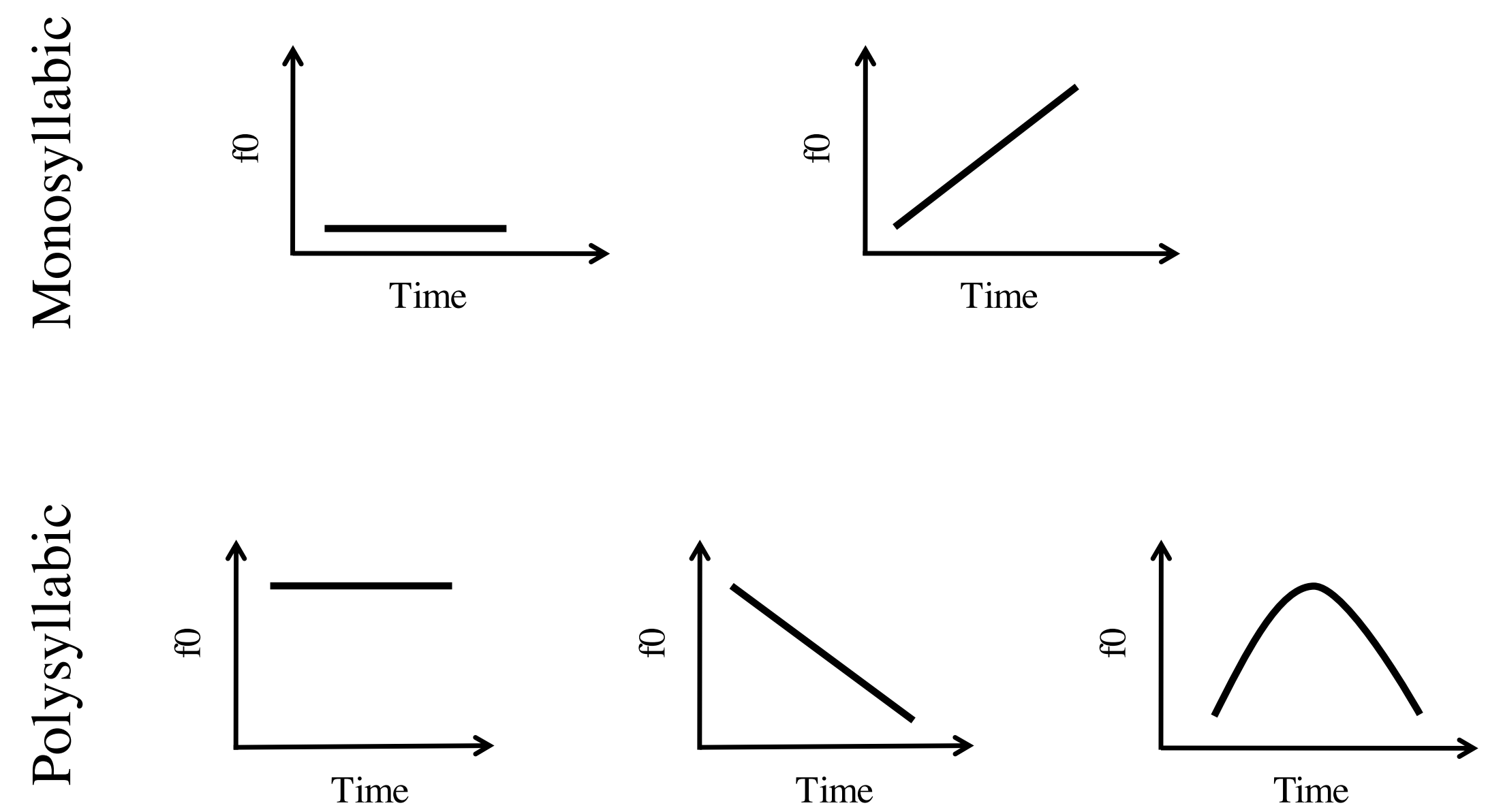
Monosyllabic
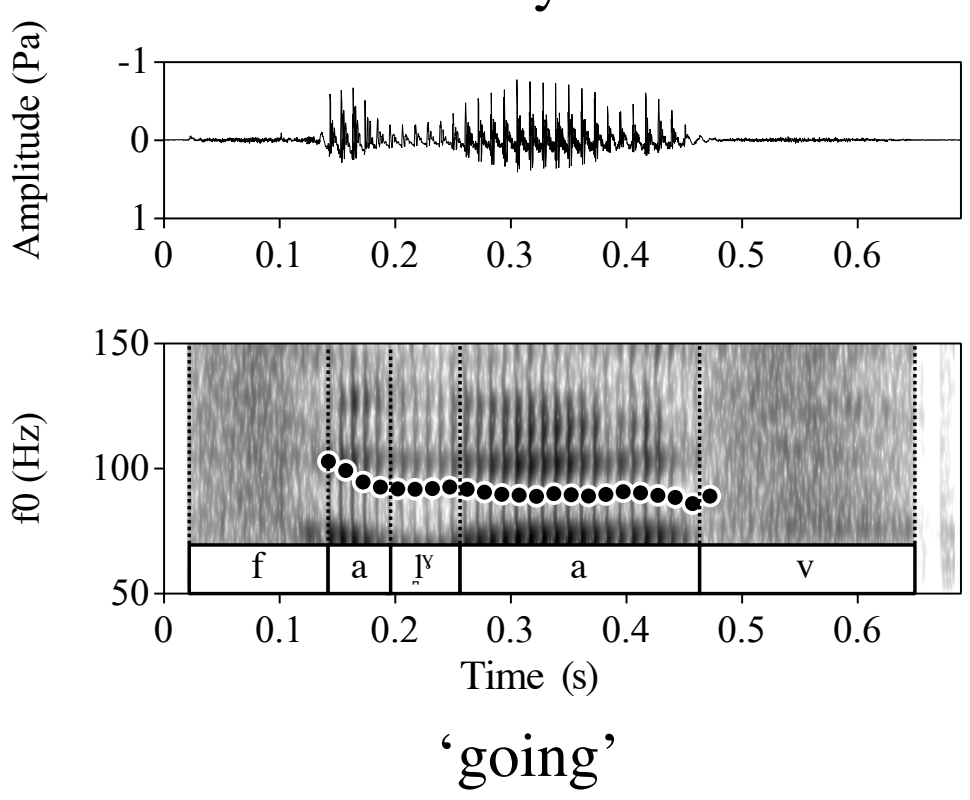

Polysyllabic
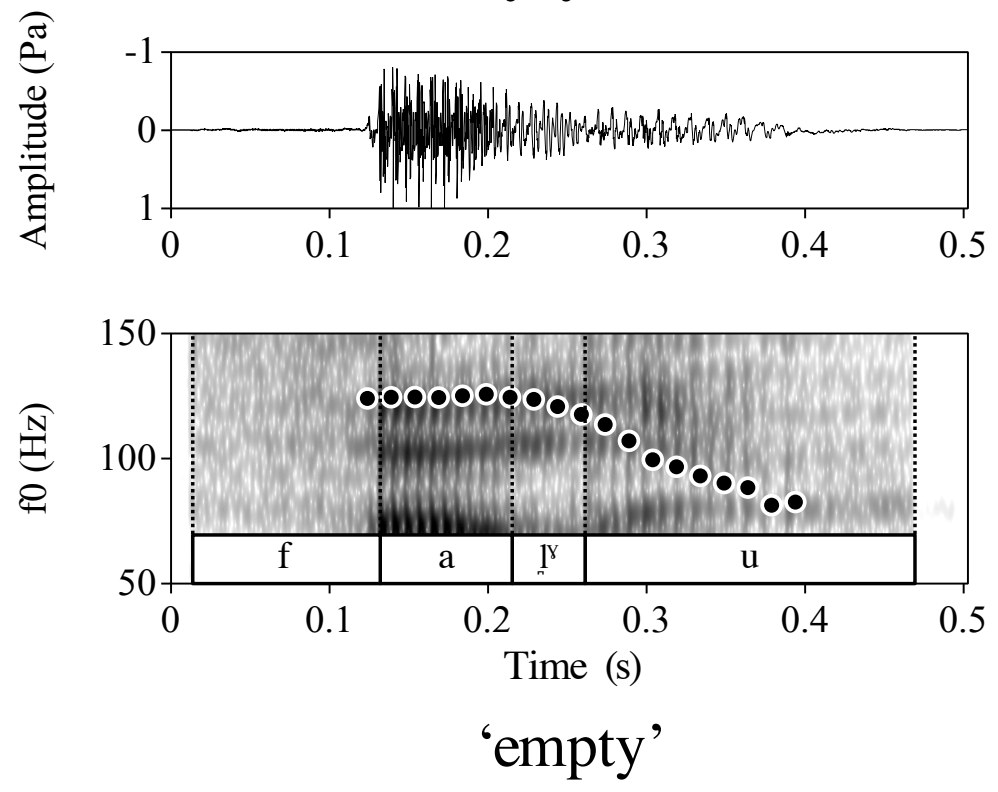
Figure 1: Percentage of people over the age of three able to speak Gaelic according to the 2011 Census (colour online). ${ }^{\mathrm{i}}$

Figure 2: Formant measurements of the Gaelic monophthongs (Bark).

Figure 3: Schematised pitch traces for Gaelic word accents.

Figure 4: Spectrograms and pitch traces illustrating the word accent contrast between falbh 'going' (monosyllabic) vs. falamh ‘empty' (polysyllabic).

\footnotetext{
${ }^{\mathrm{i}}$ Attribution: SkateTier.

(https://commons.wikimedia.org/wiki/File:Scots_Gaelic_speakers_in_the_2011_census.png), "Scots Gaelic speakers in the 2011 census", https://creativecommons.org/licenses/by-sa/3.0/legalcode.
} 
Table 1: Consonant table for Gaelic. Non-palatalised consonants are shown in the top of the cell, and palatalised below.

\begin{tabular}{|c|c|c|c|c|c|c|c|c|c|c|}
\hline & Bilabial & $\begin{array}{l}\text { Labio- } \\
\text { dental }\end{array}$ & Dental & Alveolar & $\begin{array}{c}\text { Post- } \\
\text { alveolar }\end{array}$ & Palat & & Vel & & Glottal \\
\hline Plosive & $\begin{array}{ll}p^{\text {h }} & p \\
p^{\text {jh }} & p^{j}\end{array}$ & & $\mathrm{t}^{\mathrm{h}} \quad \mathrm{t}$ & & $t^{\text {h }} \quad t \int$ & $c^{\mathrm{h}}$ & c & $\mathrm{k}^{\mathrm{h}}$ & $\mathrm{k}$ & \\
\hline Nasal & $\mathrm{m}$ & & $\begin{array}{l}\mathrm{n}^{\mathrm{Y}} \\
\mathrm{n}^{\mathrm{j}}\end{array}$ & $\mathrm{n}$ & & & & & & \\
\hline Tap/ trill & & & & $\begin{array}{l}f \\
f^{j}\end{array}$ & & & & & & \\
\hline Fricative & & $\begin{array}{ll}\mathrm{f} & \mathrm{v} \\
\mathrm{f} & \\
\end{array}$ & & $\mathrm{S}$ & $\int$ & ç & & $\mathrm{x}$ & X & $\mathrm{h}$ \\
\hline Approximant & & & & & & & $\mathrm{j}^{\mathrm{a}}$ & & & \\
\hline $\begin{array}{c}\text { Lateral } \\
\text { approximant }\end{array}$ & & & $\begin{array}{l}1^{\mathrm{Y}} \\
j^{\mathrm{j}}\end{array}$ & 1 & & & & & & \\
\hline
\end{tabular}

${ }^{a}$ Oftedal (1956:113) additionally reports a distinction in some speakers from the east coast of Lewis between $/ \mathrm{j} /$ and /j/, for example in ionnsaich ‘teach, learn!' /jẽũsıç/ and dh’ionnsaich ‘taught, learned’ /jẽũsiç/. Our participant is from the north-west of Lewis so does not make this distinction. 
Table 2: Consonant sample words (phonemic transcription).

\begin{tabular}{|c|c|c|c|c|c|c|c|}
\hline Phoneme & Gaelic & IPA & Gloss & Phoneme & Gaelic & IPA & Gloss \\
\hline \multirow[t]{3}{*}{$\mathrm{p}^{\mathrm{h}}$} & poll & $\mathrm{p}^{\mathrm{h}}$ oul ${ }^{\mathrm{Y}}$ & mud & $\mathrm{p}^{\mathrm{jh}}$ & piuthar & $\mathrm{p}^{\mathrm{hj}} \mathrm{u} . \partial \mathrm{r}$ & sister \\
\hline & puing & $\mathrm{p}^{\mathrm{h}} \partial \mathrm{in}_{n}^{\mathrm{j}} \mathrm{c}$ & point & & peann & $\mathrm{p}^{\mathrm{hj}} \mathrm{aunn}^{\mathrm{X}}$ & pen \\
\hline & capall & $\left.\mathrm{k}^{\mathrm{h}} \mathrm{a}^{\mathrm{h}} \mathrm{p}\right|^{\mathrm{Y}}$ & mare & & cipean & $\mathrm{k}^{\mathrm{h}} \mathrm{i}^{\mathrm{h}} \mathrm{p}$ & peg \\
\hline \multirow[t]{3}{*}{$\mathrm{p}$} & bò̀ & po: & cow & $p^{j}$ & beàrr & $p^{\mathrm{j}}$ a:r & cut \\
\hline & buidhe & pui.ə & yellow & & beò & $\mathrm{p}^{\mathrm{j}} \mathrm{o}$ & alive \\
\hline & obair & opI ${ }^{\mathrm{j}}$ & work & & ribe & rip’ & trap, snare \\
\hline \multirow[t]{3}{*}{$\mathrm{t}^{\mathrm{h}}$} & tog & $\mathrm{t}^{\mathrm{h}} \mathrm{ok}$ & lift & $t \int^{h}$ & teth & $t \int^{\text {h }} e$ & hot \\
\hline & tuigsinn & $\mathrm{t}^{\mathrm{h}} \mathrm{ik} \int \operatorname{in}^{\mathrm{j}}$ & understanding & & teòclaid & $\mathrm{t} \int^{\mathrm{h}} \mathrm{r}^{\mathrm{h}} \mathrm{kl}_{\mathrm{n}^{\mathrm{y}}}^{\mathrm{I}} \mathrm{It} \int$ & chocolate \\
\hline & bata & $\mathrm{pa}^{\mathrm{h}}$ to & stick & & taitinn & $t^{h} a i^{h} t \int \operatorname{tin}^{j}$ & please (verb) \\
\hline \multirow[t]{3}{*}{$\underline{t}$} & doras & tarəs & door & ts & dealbh & $\mathrm{t} \int \mathrm{al}{ }^{\mathrm{Y}} \mathrm{av}$ & picture \\
\hline & duine & $\operatorname{tin}_{n}^{\mathrm{j} \partial}$ & anyone & & $\underline{\text { deoch }}$ & $t \int 0 x$ & drink \\
\hline & fada & fato & long & & maide & matfo & beam \\
\hline \multirow[t]{3}{*}{$\mathrm{k}^{\mathrm{h}}$} & caol & $\mathrm{k}^{\mathrm{h}} \mathrm{w}: \mathrm{I}^{\mathrm{Y}}$ & thin & $\mathrm{c}^{\mathrm{h}}$ & ciall & $\left.\mathrm{c}^{\mathrm{h}} \mathrm{ij}\right]^{\mathrm{Y}}$ & reason \\
\hline & çuibhle & $\mathrm{k}^{\mathrm{h}}$ əilə & wheel & & ceòl & $c^{\mathrm{h}} \partial \mathrm{I}^{\mathrm{Y}}$ & music \\
\hline & aça & $\mathrm{a}^{\mathrm{h}} \mathrm{kə}$ & at them & & aice & $\mathrm{e}^{\mathrm{h}} \mathrm{c}$ & at her \\
\hline \multirow[t]{3}{*}{$\mathrm{k}$} & gaol & ku: $i^{\mathrm{Y}}$ & love & $\mathrm{c}$ & geal & $\mathrm{cal}^{\mathrm{X}}$ & white \\
\hline & guidhe & kui.ə & wish & & geòla & $\cos 1^{\mathrm{\gamma} \partial}$ & yawl \\
\hline & agad & akət & at you & & aige & $\varepsilon c ə$ & at him \\
\hline $\mathrm{f}$ & fuar & für & cold & $\mathrm{f}^{\mathrm{j}}$ & fion & fian & wine \\
\hline $\mathrm{v}$ & $\underline{\text { bha }}$ & va & was & & & & \\
\hline $\mathrm{s}$ & sùil & su:l & eye & $\int$ & seinn & $\int \partial \mathrm{in}^{\mathrm{j}}$ & singing \\
\hline $\mathrm{x}$ & chaidh & xai & went & ç & $\underline{\text { chì }}$ & çi: & will see \\
\hline y & dhaibh & yaiv & for them & $\mathrm{j}$ & $\underline{\mathrm{dh}}$ 'ith & jiç & ate \\
\hline $\mathrm{h}$ & $\underline{\text { fhuair }}$ & huər $^{\mathrm{j}}$ & obtained & & & & \\
\hline $\mathrm{m}$ & math & mah & good & & & & \\
\hline \multirow[t]{7}{*}{$n^{x}$} & nach & $n^{y} a x$ & not $^{\mathrm{a}}$ & $n^{j}$ & neach & $n^{\mathrm{j}} \mathrm{ax}$ & person \\
\hline & Anna & $\operatorname{ann}^{\mathrm{y}} \partial$ & Anna & & nighean & $n^{\mathrm{j}} \mathrm{i} . . n$ & daughter \\
\hline & seann & $\operatorname{Saun}^{\mathrm{X}}$ & old & & bainne & pon $n^{\mathrm{j}} \curvearrowright$ & milk \\
\hline & & & & & seinn & $\int \partial \mathrm{in}^{\mathrm{j}}$ & singing \\
\hline & & & & $\mathrm{n}$ & mo nighean & mo ni.ən & my daughter \\
\hline & & & & & banais & penis & wedding \\
\hline & & & & & sean & $\int \varepsilon n$ & grandfather \\
\hline \multirow[t]{6}{*}{$1^{\mathrm{Y}}$} & loch & $\left.\right|^{1} \mathrm{ox}$ & lake & $1^{\mathrm{j}}$ & leabaidh & $\perp^{\mathrm{j}}$ api & bed \\
\hline & callaid & $\mathrm{kaln}^{\mathrm{Y}} \mathrm{at} \int$ & fence & & cailleach & $\mathrm{k}^{\mathrm{h}} \mathrm{a}_{\sim}^{\mathrm{j}} \mathrm{j}$ & old woman \\
\hline & dall & $\operatorname{taul}^{\mathrm{X}}$ & blind & & caill & $\mathrm{k}^{\mathrm{h}_{\mathrm{ai}} \mathrm{l}_{\mathrm{j}}^{\mathrm{j}}}$ & lose \\
\hline & & & & 1 & mo & mo lapi & my bed \\
\hline & & & & & leabaidh & $\mathrm{k}^{\mathrm{h}} \mathrm{alox}$ & cockerel \\
\hline & & & & & coileach & ta: 1 & delay \\
\hline \multirow[t]{3}{*}{ ᄃ } & ràdh & ra: & saying & $f^{j}$ & ri & $\mathrm{f}^{\mathrm{j}} \mathrm{i}$ & to \\
\hline & aran & aran & bread & & aire & $\mathrm{ar}^{\mathrm{j} \partial}$ & attention \\
\hline & car & kar & somewhat & & air & $\varepsilon \mathrm{\rho}^{\mathrm{j}}$ & on \\
\hline
\end{tabular}


${ }^{a}$ The velar fricative $/ \mathrm{x} /$ is realised as $[\chi]$ following back vowels (including $/ \mathrm{a} /$ in a velarised environment). So nach $/ \mathrm{n}^{\mathrm{y}} \mathrm{ax} /$ is realised as $\left[\mathrm{n}^{\mathrm{y}} \mathrm{a}\right]$ ]. 
Table 3: Lenition mutations (phonemic transcription). Where there are differences between broad and slender consonants, these are shown. Where not, the mutated variants are the same as those shown. The prefix mo means 'my' and causes lenition.

\begin{tabular}{|c|c|c|c|c|c|c|}
\hline Phoneme & Lenited & Gaelic unlenited & IPA & Gaelic lenited & IPA & Gloss \\
\hline $\mathrm{p}^{\mathrm{h}}$ & $\mathrm{f}$ & pòg & $\mathrm{p}^{\mathrm{h}} \mathrm{ok}$ & mo phòg & mo fo:k & (my) kiss \\
\hline $\mathrm{p}$ & $\mathrm{v}$ & bò & po: & mo bhò & mo vo: & (my) cow \\
\hline $\mathrm{t}^{\mathrm{h}}$ & $\mathrm{h}$ & taigh & $\mathrm{t}^{\mathrm{h}} \partial \mathrm{i}$ & mo thaigh & mo həi & (my) house \\
\hline $\mathrm{t} \int^{\mathrm{h}}$ & $\mathrm{h}$ & tìde & $t^{h}{ }^{h} \mathrm{it} \int \partial$ & mo thìde & mo hittəo & (my) time \\
\hline $\mathrm{t}$ & y & dachaigh & taxi & mo dhachaigh & mo yaxi & (my) home \\
\hline ts & $\mathrm{j}$ & dealbh & t falav & mo dhealbh & mo jalav & (my) picture \\
\hline $\mathrm{k}^{\mathrm{h}}$ & $\mathrm{x}$ & cat & $\mathrm{k}^{\mathrm{h}} \mathrm{a}^{\mathrm{h}_{\mathrm{t}}}$ & mo chat & $\operatorname{mox} a^{h} t$ & (my) cat \\
\hline$c^{h}$ & ç & ceòl & $\mathrm{c}^{\mathrm{h}_{\mathrm{h}}} \mathbf{n}^{\mathrm{Y}}$ & mo cheòl & mo ço: $]^{\mathrm{Y}}$ & (my) music \\
\hline $\mathrm{k}$ & y & gaol & kw: $]^{\mathrm{Y}}$ & mo ghaol & mo yui: $1^{\mathrm{y}}$ & (my) love \\
\hline $\mathrm{c}$ & $\mathrm{j}$ & geòla & $\operatorname{co:} 1^{\gamma} \partial$ & mo gheòla & mo jo: ${ }^{\mathrm{Y}} \partial$ & (my) yawl \\
\hline $\mathrm{m}$ & $\mathrm{v}$ & $\underline{\text { muc }}$ & $m \tilde{u}^{\mathrm{h}} \mathrm{k}$ & mo mhuc & mo vũ $\tilde{\mathrm{h}}^{\mathrm{k}}$ & (my) pig \\
\hline $\mathrm{f}$ & $\varnothing$ & facal & $\mathrm{fa}^{\mathrm{h}} \mathrm{kal}^{\mathrm{Y}}$ & mo fhacal & $\mathrm{m} \mathrm{a}^{\mathrm{h}} \mathrm{k}^{\mathrm{r}}{ }^{\mathrm{Y}}$ & (my) word \\
\hline $\mathrm{s}$ & $\mathrm{h}$ & sùil & su:l & mo shùil & mo hu:l & (my) eye \\
\hline $\int$ & ç & seòmar & So:mər & mo sheòmar & mo ço:mər & (my) room \\
\hline $1^{\mathrm{j}}$ & 1 & leabaidh & $\underbrace{\mathrm{j}} \mathrm{api}$ & mo leabaidh & mo lapi & (my) bed \\
\hline$n^{\mathrm{j}}$ & $\mathrm{n}$ & nighean & $n^{\mathrm{j}} \mathrm{j}$. .ən & mo nighean & mo ni.ən & (my) daughter \\
\hline
\end{tabular}


Table 4: Gaelic oral monophthongs (phonemic transcription).

\begin{tabular}{|c|c|c|c|c|c|c|c|}
\hline Phoneme & Gaelic & IPA & Gloss & Phoneme & Gaelic & IPA & Gloss \\
\hline i & ri & $\mathrm{r}^{\mathrm{j}} \mathrm{i}$ & to & i: & chì & çi: & will see \\
\hline $\mathrm{e}$ & teth & $t^{\mathrm{h}} \mathrm{e}$ & hot & e: & tè & $t \int^{h} e:$ & woman \\
\hline$\varepsilon$ & bean & pen & wife & $\varepsilon:$ & Gàidheal & ke:.əli ${ }^{\mathrm{Y}}$ & Gael \\
\hline $\mathrm{a}$ & bata & $\mathrm{pa}^{\mathrm{h}}{ }_{\mathrm{t}} \mathrm{g}$ & stick & a: & bà̀ta & pa: tro & boat \\
\hline o & boc & $p o^{h} k$ & goat & o: & bòc & po: ${ }^{\mathrm{h}} \mathrm{k}$ & swell \\
\hline o & bog & pok & soft & o: & bò & po: & cow \\
\hline $\mathrm{u}$ & curr & kur & put & u: & ùr & uir & new \\
\hline $\mathrm{w}$ & turadh & $\mathrm{t}^{\mathrm{h}}$ urəy & dry weather & u: & caol & $\mathrm{k}^{\mathrm{h}} \mathrm{w}: \mathrm{l}^{\mathrm{Y}}$ & thin \\
\hline$\gamma$ & tagh & tr & choose & $\gamma:$ & adhbhar & r:vər & cause \\
\hline
\end{tabular}


Table 5: Gaelic nasal monophthongs (phonemic transcription).

\begin{tabular}{|c|c|c|c|c|c|c|c|}
\hline Phoneme & Gaelic & IPA & Gloss & Phoneme & Gaelic & IPA & Gloss \\
\hline$\tilde{1}$ & ceangal & $\mathrm{k}^{\mathrm{h}} \tilde{\mathrm{1}} . \mathrm{al}^{\mathrm{Y}}$ & connection & $\tilde{\mathrm{i}}$ & innse & I::əa & telling \\
\hline$\tilde{\mathrm{e}}$ & am faic & əm fể $\tilde{e}^{\mathrm{h}} \mathrm{k}$ & will see & $\tilde{\mathrm{e}}$ & chan $\underline{\mathrm{e}}$ & $\operatorname{xan}^{\mathrm{j}} \tilde{\mathrm{e}}:$ & it is not \\
\hline$\tilde{\varepsilon}$ & teanga & $t \int^{\mathrm{h}} \tilde{\varepsilon} \mathrm{k} \partial$ & tongue & $\tilde{\varepsilon}$ & sèimh & $\int \tilde{\varepsilon}: V$ & gentle \\
\hline$\tilde{a}$ & abhhainn & ãviñ ${ }^{\mathrm{j}}$ & river & $\tilde{a}$ & tàmh & thãav & $\begin{array}{l}\text { rest, } \\
\text { quiet }\end{array}$ \\
\hline$\tilde{\mathbf{o}}$ & cnoc & $\mathrm{kr} \tilde{\partial}^{\mathrm{h}} \mathrm{k}$ & hill & $\tilde{\jmath}$ & Dòmhnall & tก̃:.ə| ${ }^{\mathrm{Y}}$ & Donald \\
\hline$\tilde{o}$ & mothachadh & mõ.əxәу & perceiving & $\tilde{O Z}$ & Didòmhnnaich & tfi'tõ̃.niç & Sunday \\
\hline$\tilde{\mathrm{u}}$ & muc & $m \tilde{u}^{h} \mathrm{k}$ & pig & $\tilde{\text { uี }}$ & unnsa & ũisə & ounce \\
\hline$\tilde{\mathrm{u}}$ & cruinneachadh & $\mathrm{k}^{\mathrm{h}}$ rũnñ & gathering & นี: & naomh & $n^{8}$ บũ:v & saint \\
\hline$\tilde{\gamma}$ & eanchainn & $\tilde{\gamma}$ nəxiñn & brain & $\tilde{\gamma}$ & faoin & fr̆rnn $n^{\mathrm{j}}$ & $\operatorname{mad}$ \\
\hline
\end{tabular}


Table 6: Gaelic diphthongs (phonemic transcription).

\begin{tabular}{|c|c|c|c|c|c|c|c|}
\hline Phoneme & Gaelic & IPA & Gloss & Phoneme & Gaelic & IPA & Gloss \\
\hline \multirow[t]{3}{*}{ iə } & biadh & piəy & food & ei & tịll & $\mathrm{t} \int \mathrm{eil}_{n}^{\mathrm{j}}$ & return \\
\hline & ciall & $\mathrm{c}^{\mathrm{h}} \mathrm{iol}^{\mathrm{V}}$ & reason & & cinnteach & $c^{h} \operatorname{ein}_{n}^{j} t \int^{h} \partial x$ & certain \\
\hline & fion & fion & wine & & grinn & $k r^{\mathrm{j}} \mathrm{ein}^{\mathrm{j}}$ & elegant \\
\hline \multirow[t]{3}{*}{ ia } & beul & $\operatorname{pial}^{\mathrm{Y}}$ & face & əi & soillse & səi $\left.\right|_{n} ^{j} \int \partial$ & light \\
\hline & brèagha & $p^{j}$ ia.a & beautiful & & cuibhle & $\mathrm{k}^{\mathrm{h}} \partial$ ilə & wheel \\
\hline & feuch & fiax & try & & muinntir & $\operatorname{moin}_{n}^{\mathrm{j}} \mathrm{t} \int^{\mathrm{h}} \partial \mathrm{r}^{\mathrm{j}}$ & people \\
\hline \multirow[t]{3}{*}{ uə } & tuath & $\mathrm{t}^{\mathrm{h}} \mathrm{u}$ & north & ui & suidhe & sui.ə & sit \\
\hline & fuar & fuər & cold & & buidhe & pui.ə & yellow \\
\hline & ruadh & ruəy & red & & guidhe & kui.ə & wish \\
\hline \multirow[t]{3}{*}{ ua } & cuan & $\mathrm{k}^{\mathrm{h}}$ uan & ocean & $\mathrm{au}$ & call & $\mathrm{k}^{\mathrm{h}} \mathrm{aull}^{\mathrm{Y}}$ & loss \\
\hline & a-nuas & วñ ${ }^{\mathrm{X}}$ uas & down & & samhradh & saurəy & summer \\
\hline & duan & tuan & song & & ceann & $\mathrm{c}^{\mathrm{h}} \mathrm{aun}_{n}^{\mathrm{X}}$ & head \\
\hline \multirow[t]{3}{*}{ ai } & dhaibh & yaiv & for them & ou & poll & $\mathrm{p}^{\mathrm{h}} \mathrm{oul}_{\mathrm{n}}^{\mathrm{Y}}$ & mud \\
\hline & cainnt & $\mathrm{k}^{\mathrm{h}} \mathrm{ain}_{n}^{\mathrm{j}} \mathrm{t} \mathrm{f}^{\mathrm{h}}$ & speech & & donn & $\operatorname{toun}^{\mathrm{X}}$ & brown \\
\hline & taing & $t^{\mathrm{t}^{\mathrm{h}}} \mathrm{ain}^{\mathrm{j}} \mathrm{c}$ & thanks & & leam & loum & at me \\
\hline
\end{tabular}


Table 7: Pairs of words illustrating the word accent contrast (phonemic transcription).

Monosyllabic words are to the left, polysyllabic comparison words to the right.

\begin{tabular}{|c|c|c|c|c|c|c|c|}
\hline Syllabicity/Accent & Word & IPA & English & Syllabicity/Accent & Word & IPA & English \\
\hline Monosyllabic/Accent 1 & bò & po: & cow & Polysyllabic/Accent 2 & bogha & po.ə & rockpool \\
\hline Monosyllabic/Accent 1 & gu leòr & kə $1_{n}^{\mathrm{j}}$ o: & enough & Polysyllabic/Accent 2 & leabhar & 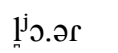 & book \\
\hline Monosyllabic/Accent 1 & sùil & su:1 & eye & Polysyllabic/Accent 2 & ubhal & u. $\left.\partial\right|^{\mathrm{Y}}$ & apple \\
\hline Monosyllabic/Accent 1 & falbh & faln ${ }^{\mathrm{Y}} \mathrm{av}$ & going & Polysyllabic/Accent 2 & falamh & faln $\mathrm{n}^{\mathrm{y}} \cdot \mathrm{u}$ & empty \\
\hline Monosyllabic/Accent 1 & tinn & $\mathrm{t} \int^{\mathrm{h}} \mathrm{ein}^{\mathrm{j}}$ & ill & Polysyllabic/Accent 2 & tighinn & $t \int^{h} \mathrm{i} . \partial n^{j}$ & coming \\
\hline Monosyllabic/Accent 1 & ainm & anam & name & Polysyllabic/Accent 2 & anam & anəm & soul \\
\hline Monosyllabic/Accent 1 & ràmh & rãv & oar & Polysyllabic/Accent 2 & rathad & ra.ət & road \\
\hline Monosyllabic/Accent 1 & $\operatorname{sinn}$ & Sain ${ }^{\mathrm{j}}$ & we & Polysyllabic/Accent 2 & sithinn & $\int i . n^{j}$ & venison \\
\hline
\end{tabular}

